\title{
PEMANFAATAN LIMBAH ARES POHON PISANG MENJADI MANISAN ARES PISANG
}

\author{
${ }^{1)}$ Yenny Sri Margianti, ${ }^{2}$ Djalal Su'udi \\ ${ }^{1)}$ Program Studi Agrobisnis, Fakultas Pertanian, Universitas Bojonegoro \\ Jalan Lettu Suyitno No.02, Bojonegoro 62119, Jawa Timur \\ Email : ${ }^{1)}$ yennysrimargiantimpd@gmail.com ${ }^{2)}$ djalalsuudi@gmail.com
}

\begin{abstract}
The processed of banana ares sweets in the community is not yet popular because the community do not know to process banana ares sweets. This study aimed to investigate the making process of banana ares into banana ares sweets and to find out the level of reception of panelists towards the concentration of the addition of cinnamon in the processed banana ares sweets. The study was conducted three processed sweets, namely, Processed A: heating 30 minutes + cinnamon 5 grams + without color, Processed B: heating 40 minutes + cinnamon 8 grams + green color, Processed $\mathrm{C}$ : heating 50 minutes + cinnamon 10 grams + red color. Each Processed was given banana ares 300 grams + granulated sugar 80 grams +0.5 teaspoons of salt acid added by $500 \mathrm{ml}$ water and soaking banana ares with whiting water for 10 hours. The sampling of panelists was carried out on purpose, with a population of 25 students of University Bojonegoro. Based on a one-way analysis (ANOVA) show that there are significant differences sweets in aroma and taste, but there in terms of color and texture there is no significant difference. Based on average organoleptic assessment by panelists, the best treatment was Processed C, namely, Aroma (2.70), Flavor (3.36), Texture (2.80) and Color (3.00). Processed C was $500 \mathrm{ml}$ boiled water + granulated sugar 80 grams + cinnamon 10 grams + ares that had been diced boiled for 50 minutes.
\end{abstract}

Keywords : ares, waste, sweets, acceptance rate.

\section{PENDAHULUAN}

Indonesia Negara penghasil beraneka ragam buah-buahan, salah satunya yang populer dimasyarakat pisang. Tanaman pisang banyak dibudidayakan oleh masyarakat. Di Bojonegoro hampir semua desa, masyarakat menanam tanaman pisang, dengan luas 51.245 Ha Dari data statistik Dinas Pertanian kabupaten Bojonegoro (2018). Pisang yang banyak ditanam dipedesaan kabupaten Bojonegoro adalah jenis pisang kapok (Musa Acuminata Balbisiana). Bagian tanaman pisang seperti buah, bonggol, daun, batang dan jantung pisang dapat dimanfaatkan.

Semua bagian tanaman memiliki manfaat masing-masing. Masyarakat pada umumnya mengetahui hanya bagian buah dan bunga tanaman pisang yang dapat dimakan. Buah pisang selain dimakan dalam keadaan buah, pisang sering diolah menjadi makanan ringan atau kudapan. Sedangkan bunga pisang sering dimasak sebagai sayur pelengkap. Pada musim kemarau, biasanya kekurangan makanan ternak ruminansia (kambing, domba) karena rumput jarang didapatkan, sehingga dapat memanfaatkan batang pisang sebagai makanan ternak, dengan cara memotong batang pisang kecil-kecil. Selain itu kulit pisang dapat dibuat cuka melalui proses fermentasi yang menghasilkan alkohol dan asam cuka. Daun pisang dapat dimanfaatkan sebagai pembungkus makanan seperti pembungkus botok, lemper.

Di Bali batang pisang yang masih muda diolah menjadi hidangan khas bali yaitu jukut ares (sup batang pisang) dan jantung pisang diolah menjadi hidangan tumis jantung pisang. 
Hati batang tanaman pisang disebut Ares, yang letaknya bagian dalam batang pisang belum dimanfaatkan secara optimal oleh masyarakat. Bagian hati batang pisang cenderung dibuang menjadi limbah yang merugikan lingkungan. Ternyata ares pisang memiliki serat yang tinggi, dan menurut ahli gizi ares pisang mengandung serotonin, norepinefrin, tanin, hidroksitriptamin, dopamine, vitamin A, vtamin B, vitamin C, Kalium dan gula . Sedang kan menurut Apriadji (2001), ares pisang mengandung banyak kalori dan protein yang dapat menambah energi.

Ares pisang termasuk serat kasar yang sebagian besar terdiri dari selulosa. Dan merupakan satu jenis polisakarida atau karbohidrat komplek. Serat kasar ini mempunyai rantai kimiawi panjang sehingga sukar dicerna oleh enzim saluran pencernaan manusia walaupun diusus terdapat bakteri coli (Nurhidayati, 2006). Serat dibagi menjadi 2 golongan besar yaitu serat yang larut dalam air dan serat yang tidak larut dalam air. Dari seluruh makanan berserat yang ada hampir seluruhnya terdiri dari kombinasi kedua jenis serat tersebut. Namun komposisi serat tidak larut air umumnya lebih dominan dibandingkan serat yang larut air (Ikmal, 2009).

Dari permasalahan tersebut peneliti ingin memanfaatkan bahan ares pisang menjadi sumber makanan baru yang memiliki manfaat kesehatan bagi tubuh dan disenangi mulai anak -anak sampai orang dewasa.

Selain itu ares pisang bermanfaat bagi kesehatan, menurut ulasan Okezone dari The Health Site, sabtu 12/10/2019. Adalah dapat menurunkan berat badan,memerangi batu ginjal, mengobabati infeksi kandung kemih, menjaga kadar gula darah, hiperasiditas, mencegah sembelit dan mencegah anemia.

Masyarakat Lombok sering menyertakan ares dalam berbagai varian makanan tradisional mereka, sehingga ares lebih dikenal sebagai makanan khas daerah Lombok. Rasanya yang unik menyebabkan orang yang telah mencobanya ketagihan ingin mencoba lagi. Di daerah lain belum memanfaatkan ares pisang sebagai makanan.

Di dalam penelitian limbah ares pisang yang digunakan pisang kepok (Musa paradisiaca L) karena jenis pisang kepok banyak di tanam di pedesaan Kabupaten Bojonegoro. Limbah ares pisang kepok ini akan menjadi bahan baku olahan manisan ares pisang. Manisan dipilih sebagai produk yang menjanjikan dalam pemanfaatan ares pisang sebagai bahan baku makanan olahan. Dengan menambahkan kayu manis pada manisan ares .maka didalam penyimpanan dapat bertahan dalam waktu yang lama.

Kayu manis bermanfaat bagi kesehatan tubuh, selain itu dapat menambahkan rasa pada makanan, aroma makanan dan sebagai bahan pengawet alami. Oleh sebab itu peneliti di dalam pengolahan manisan ares pisang menambahkan kayu manis. Sebuah penelitian menyatakan bahwa kayu manis mengandung sinamaldehid yang dapat menghambat pertumbuhan bakteri gram positif dan negatif secara in vitro. Hal ini yang menyebabkan kayu manis banyak digunakan sebagai bahan pengawet alami.

Olahan manisan ares pisang di masyarakat masih belum populer karena manisan ares pisang ini merupakan makanan baru yang belum dikenal masyarakat. Masyarakat belum mengetahui bahwa batang pisang dapat dikonsumsi, tepatnya bagian dalam batang pisang (Ares).

Penelitian ini menggunakan bahan ares pisang (hati pisang) karena selama ini batang pisang terutama bagian hatinya belum dimanfaatkan oleh masyarakat tetapi cenderung dibuang sehingga akhirnya menjadi limbah. Bila ares pisang diolah menjadi manisan berarti akan mengurangi limbah batang pisang. Selain itu, hati pisang mengandung nutrisi dan vitamin yang dibutuhkan oleh tubuh. Karena itu peneliti mengambil judul Pemanfaatan Limbah Ares Pohon Pisang Menjadi Manisan Ares Pisang, 
Penelitian ini bertujuan, 1. Untuk mengetahui cara pengolahan ares pisang hingga menjadi manisan ares pisang. 2. Untuk menguji tingkat kesukaan panelis terhadap tiga macam olahan manisan ares pisang.

Penelitian ini dilaksanakan pada bulan Mei sampai Desember 2020, dan lokasi penelitian bertempat di Laboratorium Fakultas Sains dan Teknik Universitas Bojonegoro di Kabupaten Bojonegoro.

\section{PROSEDUR OLAHAN}

Peralatan penelitian yang digunakan antara lain: pisau, sendok kecil, baskom ukuran sedang, saringan, panci almunium, talenan, pengaduk, sarung tangan plastik, timbangan digital, timbangan analitik kompor dan Elpiji, mangkok kecil, sendok kecil plastik.

Bahan yang digunakan dalam pengolahan manisan ares pisang adalah Ares pisang kepok, gula pasir, garam asem, air kapur sirih, pewarna kue/alami, kayu manis, dan air.

\section{Perlakuan Olahan}

Pada awal olahan ini dimulai dengan penyediaan bahan olahan manisan ares pisang seperti ares pisang kepok, gula pasir, pewarna, kayu manis, air, air kapur sirih. Manisan Ares pisang ini dibagi menjadi 3 perlakuan olahan yaitu :

Olahan A: pemanasan 30 menit + kayu manis 5 gram + tanpa pemberian warna pada ares. Olahan B: pemanasan 40 menit + kayu manis 8 gram + pemberian warna hijau pada ares Olahan C: pemanasan 50 menit + kayu manis 10 gram + pemberian warna merah pada ares

Setiap Olahan diberikan Ares pisang 300 gram + gula pasir 80 gram $+0,5$ sendok kecil garam asem ditambahkan air $500 \mathrm{ml}$ dan perendaman ares pisang dengan air kapur sirih selama selama 10 jam.

\section{Pembuatan Manisan Ares}

Olahan A : Potong ares pisang dibentuk dadu dibersihkan dengan air, setelah itu direndam air kapur sirih jernih selama 10 jam. Lalu dicuci bersih dengan air sampai air kelihatan jernih.

Rebus air $500 \mathrm{ml}+80$ gram gula pasir +5 gram kayu manis + ares yang sudah dipotong bentuk dadu direbus selama 30 menit. Setelah itu siap diuji organoleptik.

Olahan B : Potong ares pisang dibentuk dadu dibersihkan dengan air, setelah itu direndam air kapur sirih jernih selama 10 jam. Lalu dicuci bersih dengan air sampai air kelihatan jernih. Setelah itu baru pemberian warna hijau (pewarna kue) sampai 4 jam lalu dicuci bersih.

Rebus air $500 \mathrm{ml}+80$ gram gula pasir +8 gram kayu manis + ares yang sudah dipotong bentuk dadu direbus selama 40 menit. Setelah itu siap diuji organoleptik.

Olahan C : Potong ares pisang dibentuk dadu dibersihkan dengan air, setelah itu direndam air kapur sirih jernih selama 10 jam. Lalu dicuci bersih dengan air sampai air kelihatan jernih. Setelah itu baru pemberian warna merah (pewarna kue) sampai 4 jam lalu dicuci bersih

Rebus air $500 \mathrm{ml}+80$ gram gula pasir +10 gram kayu manis + ares yang sudah dipotong bentuk dadu direbus selama 50 menit. Setelah itu siap diuji organoleptik.

Jenis data yang digunakan dalam penelitian ini adalah data primer, yang dikumpulkan dari hasil angket pengamatan panelis. Data pengamatan menggunakan instrumen atau angket . 
Jenis subjek pada penelitian ini digunakan panelis agak terlatih, dengan jumlah sampel sebanyak 25 orang mahasiswa Universitas Bojonegoro. Dimana panelis diberikan pengarahan sebelum melakukan uji organoleptik, Untuk menguji tingkat kesukaan panelis terhadap tiga olahan manisan ares meliputi apek warna, aroma, rasa dan tekstur maka digunakan Uji organoleptik. pada penelitian ini adalah uji hedonik atau uji kesukaan yang merupakan salah satu uji penerimaan. Dalam pelaksanaan nya masingmasing panelis tersebut akan diberikan 3 contoh olahan manisan ares yang akan diuji tingkat kesukaan terhadap 4 kriteria pengujian, yaitu warna, rasa, aroma dan tekstur (kemudahan digigit dan kemudahan dikunyah). Panelis menanggapi dengan cara memberikan tanda chek list $(\sqrt{ })$ sesuai dengan kriteria yang telah ditentukan pada lembar angket panelis terhadap tingkat kesukaan manisan ares berdasarkan skala hedonik, Setelah itu data penilaian dapat ditransformasikan dalam skala numerik dan selanjutnya dapat dianalisis statistik untuk interprestasinya. Kriteria penilaian uji organoleptik dengan menggunakan skala Hedonik lihat pada tabel 1 sebagai berikut.

Tabel 1. Skala Hedonik Uji Organoleptik

\begin{tabular}{llllc}
\hline \multicolumn{2}{c}{ SKALA HEDONIK } & \multicolumn{1}{c}{ Skala } \\
\cline { 1 - 3 } Warna & \multicolumn{1}{c}{ Aroma } & \multicolumn{1}{c}{ Rasa } & Tekstur & Numerik \\
\hline Suka & Suka & Enak & keras & 4 \\
Agak suka & Agak suka & agak Enak & agak keras & 3 \\
Netral & Netral & Netral & Netral & 2 \\
Agak tidak suka & Agak tidak suka & Agak tidak enak & Agak lunak & 1 \\
Tidak suka & Tidak suka & Tidak enak & Lunak & 0 \\
\hline
\end{tabular}

\section{ANALISIS DATA}

Penelitian ini merupakan penelitian jenis eksperimen menggunakan pengamatan (Sugiyono, 2013). Pengamatan dilakukan dengan alat indera seperti alat indera penglihat (warna), indera pembau (aroma), indera pengecap (rasa), indera peraba (tekstur). Hal ini sesuai Soekarto, (2002), bahwa parameter yang diukur pada pengamatan yang melibatkan alat indera manusia yaitu indera penglihat, indera penciuman, indera pengecap dan indera peraba meliputi warna, aroma, rasa, tekstur.

Uji organoleptik dilakukan untuk menguji tingkat kesukaan konsumen terhadap 4 aspek yaitu warna, rasa, aroma, dan tekstur manisan ares pisang yang dihasilkan. Hal ini sesuai dengan Kartika et al. (1988), mengatakan bahwa uji kesukaan merupakan jenis pengujian penerimaan organoleptik yang meminta panelis mengemukakan tanggapannya terhadap tingkat kesukaan berupa suka atau tidaknya terhadap sifat bahan yang diuji.

Analisis data untuk mengetahui apakah ada perbedaaan dari perlakuan Olahan menggunakan analisis variansi (ANOVA) satu arah. Masing-masing pengujian perlakuan tersebut ada 3 Olahan Manisan Ares. Apabila terdapat perbedaan yang signifikan dari hasil analisis varian (ANOVA), maka dilanjutkan uji BNT dengan taraf nyata 5\% dengan tujuan untuk mengetahui apakah ada perbedaan pada perlakuan olahan manisan ares.

\section{HASIL DAN PEMBAHASAN}

Pengujian organoleptik Olahan Manisan Ares Pisang dilakukan dengan uji hedonik menggunakan lima skala hedonik. Skala penilaian terdiri dari tidak suka/tidak enak/lunak (0), agak tidak suka/agak tidak enak/agak lunak (1), netral (2), agak suka/agak enak/agak keras (3), suka/enak/keras (4). Panelis yang dilibatkan dalam uji organoleptik sebanyak 25 orang dengan kualifikasi panelis agak terlatih. Panelis diminta menuliskan tanggapan 
dan kesan terhadap warna, aroma, rasa, dan tekstur. Hasil uji hedonik disajikan pada gambar

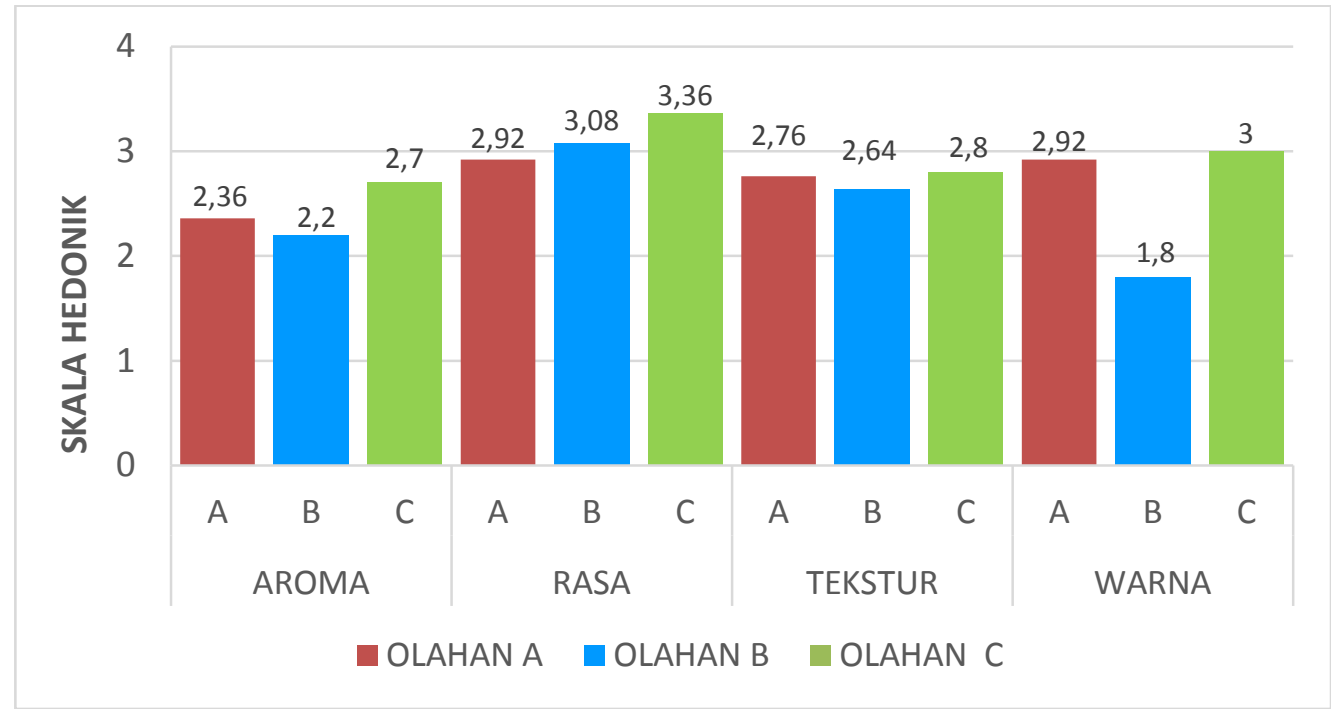

Gambar 1. Hasil Nilai Rata-Rata Uji Organoleptik Manisan Ares Pisang

Berdasarkan Hasil Nilai rata-rata tertinggi dari segi Aroma 2,7 pada Olahan C, Rasa 3,36 pada Olahan C, Tekstur 2,8 pada Olahan C, dan Warna 3,0 pada Olahan C, menunjukkan bahwa panelis menyukai pada Olahan C.

Berikut hasil nilai rata-rata penilaian Organoleptik oleh panelis terhadap Manisan Ares Pisang dan hasil Anova satu arah dengan Uji BNT 5\% ditunjukkan pada tabel 2.

Tabel 2. Hasil Nilai Rata-Rata Uji Organolepetik Manisan Ares Pisang

\begin{tabular}{ccccc}
\hline \multirow{2}{*}{ Perlakuan } & \multicolumn{4}{c}{ Rata - Rata } \\
\cline { 2 - 5 } & Aroma & Rasa & Tekstur & Warna \\
\hline A & $2,36 \mathrm{~b}$ & $2,92 \mathrm{a}$ & $2,76 \mathrm{a}$ & $2,92 \mathrm{a}$ \\
B & $2,20 \mathrm{a}$ & $3,08 \mathrm{~b}$ & $2,64 \mathrm{a}$ & $1,80 \mathrm{a}$ \\
$\mathrm{C}$ & $2,70 \mathrm{~b}$ & $3,36 \mathrm{~b}$ & $2,80 \mathrm{a}$ & $3,00 \mathrm{a}$ \\
\hline
\end{tabular}

Keterangan : Angka yang diikuti huruf yang sama pada kolom yang sama menunjukkan tidak ada beda nyata berdasarkan uji lanjut Uji BNT 5\%.

Berdasarkan tabel 2. Dari hasil statistik uji ANOVA yang dilanjutkan uji BNT, diketahui bahwa olahan $\mathrm{B}$ berbeda dari olahan $\mathrm{A}$ dan olahan $\mathrm{C}$ dari segi aroma. Olahan $\mathrm{A}$ berbeda dari olahan B dan olahan C dari segi rasa. Sedangkan dari segi tekstur dan warna dari ketiga olahan tidak berbeda. Hasil rata-rata nilai uji organoleptik olahan $\mathrm{C}$ memiliki nilai tertinggi baik dari segi aroma, rasa, tekstur dan warna, ini menunjukkan panelis menyukai pada perlakuan/olahan $\mathrm{C}$. Olahan $\mathrm{C}$ adalah Rebus air $500 \mathrm{ml}+80$ gram gula pasir +10 gram kayu manis + ares yang sudah dipotong bentuk dadu direbus selama 50 menit. 
Jurnal Viabel Pertanian Vol. 14 No. 2 November 2020

p-ISSN: 1978-5259 e-ISSN: 2527-3345

Copyright@UNISBA Blitar, http://ejournal.unisbablitar.ac.id/index.php/viabel

Yenny Sri Margianti \& Djalal Su'udi, 2020. Pemanfaatan Limbah Ares Pohon Pisang Menjadi

Manisan Ares. Journal Viabel Pertanian. (2020), 14(2) 64-72

Rasa

Hasil Analisis Sidik Ragam Rasa Manisan Ares Pisang dapat dilihat pada tabel 3.

Tabel 3. Hasil Analisis Sidik Ragam Rasa Manisan Ares Pisang

\begin{tabular}{crrrrrr}
\hline $\begin{array}{c}\text { Sumber } \\
\text { Keragaman }\end{array}$ & $J K$ & $d b$ & KT & $F$ & P-value & F Tabel \\
\hline BetweenGroups & 37,12 & 24 & 1,546667 & 2,416667 & 0,004267 & 1,73708 \\
Within Groups & 32 & 50 & 0,64 & & & \\
\hline Total & 69,12 & 74 & & & & \\
\hline
\end{tabular}

Analisis sidik ragam tabel 3 menunjukkan penilaian kesukaan rasa manisan ares pisang oleh panelis beda nyata dimana $\mathrm{F}$ hitung > F tabel 5\%. Hal ini menunjukankan, bahwa aspek rasa manisan ares pisang memberikan pengaruh nyata terhadap rasa kesukaan pada panelis.

Dari penilaian uji organoleptik terhadap aspek rasa pada manisan ares pisang, olahan manisan ares $\mathrm{C}$ memiliki nilai rata rata tertinggi yaitui 3,36 (agak suka/agak enak).Hal ini menunjukan olahan $\mathrm{C}$ lebih disukai panelis. Pada tabel 2. Olahan B dan C tidak berbeda menunjukkan kedua olahan tersebut perlakukan mendapatkan nilai agak suka/agak enak oleh panelis, yang mengakibatkan nilai organoleptik rasa pada manisan ares pisang memiliki nilai hampir sama. Kayu manis memiliki bau yang sangat kuat sehingga panelis tidak bisa membedakan rasa. Selain itu kepekaan rangsangan sel sel sensorik panelis tidak sama Menurut Wahidah (2010), cita rasa ditentukan rangasangan oleh sel sel sensorik pada lidah. Kayu manis memiliki citra rasa yang kuat. Dengan menambahkan kayu manis pada olahan manisan ares pisang dapat menambah selera atau meningkatkan selera Soeparno, (1992).

\section{Tekstur}

Hasil Analisis Sidik Ragam Tekstur Manisan Ares Pisang dapat dilihat pada tabel 4.

Tabel 4. Hasil Analisis Sidik Ragam Tekstur Manisan Ares Pisang

\begin{tabular}{crrccrrr}
\hline $\begin{array}{c}\text { Sumber } \\
\text { Keragaman }\end{array}$ & \multicolumn{1}{c}{$J K$} & $d b$ & $K T$ & $F$ & P-value & F Tabel \\
\cline { 1 - 4 } BetweenGroups & 147,04 & 24 & 6,126667 & 1,003275 & 0,473306 & 1,73708 \\
Within Groups & 458 & 75 & 6,106667 & & & \\
\cline { 1 - 2 } Total & 605,04 & 99 & & & & \\
\hline
\end{tabular}

Analisis sidik ragam tabel 4 menunjukkan penilaian kesukaan tekstur manisan ares pisang terdapat perbedaan tidak signifikan oleh panelis Hal ini disebabkan walaupun lamanya pemanasan tiap olahan berbeda tetapi tekstur ares pisang memiliki serat yang kuat.

Dari hasil penilaian uji organoleptik terhadap tekstur pada manisan ares pisang menunjukkan bahwa panelis lebih menyukai Olahan $\mathrm{C}$, karena memiliki nilai rata rata lebih tinggi dari tiga olahan manisan ares pisang yaiyu 2,8 (agak keras). Pada tabel 2. Secara statistik menunjukkan untuk semua perlakukan mendapatkan nilai agak agak keras oleh panelis, karena tekstur ares pisang memiliki serat yang kuat.

Tekstur adalah penginderaan yang berkaitan dengan kekerasan pada suatu makanan. Tekstur juga harus diperhatikan didalam pelohan makana karena tekstur dapat 
mempengaruhi citra makanan. Menurut De Man, (1977), Tekstur dalam pengolahan makanan perlu diperhatikan kelunakan dan kerenyahnya. Ciri-ciri yang sering diabaikan adalah kekerasan, kekohesifan dan kandungan air. Pengamatan tekstur pada ares pisang dilihat dari kemudahan dikunyah dan digigit, agak sulit lunak dikarenakan ares pisang memiliki serat yang kuat.

\section{Aroma}

Hasil Analisis Sidik Ragam Aroma Manisan Ares Pisang lihat tabel 5 berikut.

Tabel 5. Hasil Analisis Sidik Ragam Aroma Manisan Ares Pisang

\begin{tabular}{|c|c|c|c|c|c|c|}
\hline \multirow{2}{*}{$\begin{array}{l}\text { Sumber } \\
\text { Keragaman }\end{array}$} & \multirow[t]{2}{*}{$J K$} & \multirow[t]{2}{*}{$d b$} & \multirow{2}{*}{$K T$} & \multirow[t]{2}{*}{$F$} & \multirow[t]{2}{*}{$P$-value } & F Tabel \\
\hline & & & & & & $5 \%$ \\
\hline BetweenGroups & 37,68 & 24 & 1,57 & 2,030172 & 0,017481 & 1,73708 \\
\hline Within Groups & 38,66667 & 50 & 0,773333 & & & \\
\hline Total & 76,34667 & 74 & & & & \\
\hline
\end{tabular}

Analisis sidik ragam tabel 5 menunjukkan penilaian kesukaan aroma manisan ares pisang oleh panelis terdapat perbedaan yang signifikan. Hal ini disebabkan dengan penambahan kayu manis menyebabkan perbedaan aroma.

Pada tabel 2 terlihat penilaian panelis terhadap manisan ares pisang terdapat perbedaan dari ketiga olahan ares pisang, dimana olahan $\mathrm{A}$ dan $\mathrm{C}$ memiliki penilaian penerimaan kesukaan yang sama terhadap panelis, ternyata pemberian kayu manis 5 gram dan 10 gram tetap memberikan penilaian panelis yang sama. Hal ini disebabkan kayu manis memilik aroma yang kuat dan spesifik. Pada tabel 2, menunjukkan olahan $\mathrm{C}$ paling disukai panelis karena memiliki nilai rata rata paling tinggi uji organoleptik.

Menurut Kusumawati, dkk (2000). bahwa aroma merupakan salah satu aspek pengujian organoleptik yang menggunakan indera pembau, diperlukan panelis yang memiliki idera pembau yang tajam dan bahan yang digunakan mempunyai aroma yang khas dan menyengat . . Aroma kayu manis dapat diterima karena bahan yang digunakan mempunyai aroma spesifik dan bau yang menyengat .

\section{Warna}

Hasil Analisis Sidik Ragam Warna manisan ares pisang lihat tabel 6 berikut.

Tabel 6. Hasil Analisis Sidik Ragam Warna Manisan Ares Pisang

\begin{tabular}{lccccccc}
\hline $\begin{array}{l}\text { Sumber } \\
\text { Keragaman }\end{array}$ & $J K$ & $d b$ & $K T$ & $F$ & P-value & F Tabel \\
\hline Between Groups & 39,01333 & 24 & 1,625556 & 1,325181 & 0,197837 & 1,73708 \\
Within Groups & 61,33333 & 50 & 1,226667 & & & \\
\hline Total & 100,3467 & 74 & & & & \\
\hline
\end{tabular}

Analisis sidik ragam tabel 6 menunjukkan penilaian kesukaan warna manisan ares pisang oleh panelis tidak beda nyata dimana $\mathrm{F}$ hitung < $\mathrm{F}$ tabel 5\%. Hal ini disebabkan dengan pemberian warna pada ares pisang kurang menarik karena ares pisang sulit untuk menyerap warna dari pewarna kue. Menyebabkan panelis kurang selera untuk mencicipi 
manisan ares pisang. Pada tabel 2. panelis lebih menyukai warna olahan $\mathrm{C}$ karena memiliki rata rata penilaian organoleptk lebih tinggi yaitu 3,00.

Menurut Winarno, (1977) warna merupakan kesan pertama yang muncul dan dinilai oleh panelis. Warna merupakan parameter organoleptik yang pertama dalam penyajian karena menggunakan alat indera penglihatan. Warna yang menarik akan mengundang selera panelis untuk mencicipi produk tersebut.

\section{SIMPULAN}

Hasil uji ANOVA satu arah menunujkkan bahwa penilaian panelis terhadap manisan ares pisang memberikan pengaruh nyata pada Aroma dan Rasa. Dan memberikan pengaruh tidak nyata pada Warna dan Tekstur. Sedangkan rata-rata penilaian organoleptik oleh panelis menyukai proses olahan C baik rasa, aroma, tekstur, dan warna, karena keempat rata-rata penilaian organoleptiknya tinggi.

Proses olahan $\mathrm{C}$ adalah Rebus air 500ml tambahkan 80 gram gula pasir dan 10 gram kayu manis. Masukkan Ares yang sudah dipotong bentuk dadu direbus selama 50 menit.

Dengan adanya terobosan baru dalam pemanfaatan ares pisang sebagai manisan diharapkan juga turut mengurangi limbah sampah organik, terutama batang pisang dan meningkatkan kesejahteraan masyarakat.

Perlu adanya sosialisasi ke masyarakat, ares pisang dapat diolah menjadi manisan.

\section{DAFTAR PUSTAKA}

De MMan, J. M., 1997 . Kimia Makanan. Alih Bahasa: Kosasih P. Institut Teknologi Bandung. Bandung.

Kartika, B., P. Hastuti, dan W. Supartono. 1988. Pedoman Uji Inderawi Bahan Pangan. Yogyakarta: Pusat Antar Universitas Pangan dan Gizi Universitas Gadjah Mada.

Kusumawati, Aan, H. Ujang, dan E. Evi. 2000. Dasar-Dasar Pengolahan Hasil Pertanian I.. Central Grafika, Jakarta.

Rahayu, W.P. (2001). Penuntun Praktikum Penilaian Organoleptik. Teknologi Pangan dan Gizi. Fakultas Teknologi Pertanian Institut Pertanian. Bogor : Bogor.

Rempah Rempah Sebagai Pengawet Alami Asal Tanah Air Ibu Pertiwi, https://www.goodnewsfromindonesia.id/2017/12/26/rempah-rempah-pengawetalamai-asaltanah-air-ibu-pertiwi. Diakses tanggal 10 Agustus 2019.

Soekarto. 2002. Penilaian Organoleptik Untuk Industri Pangan dan Hasil Pertanian. Institut Pertanian Bogor. Bogor.

Soeparno, 1992. Ilmu dan Teknologi Daging. Gadjah Mada University Press, Yogyakarta.

Sugiyono. 2013. Metode Penelitian Kuantitatif, Kualitatif dan R\&D. Bandung: Alfabeta.

Susiwi. 2009, Jurnal Penilaian Organoleptik (Handout)”. FPMIPA. Universitas Pendidikan Indonesia, 2009.

Suyanti Satuhu dan Ahmad Supriyadi, 2007. Pisang, Budidaya, Pengolahan, dan prospek Pasar. Penebar Swadaya. Jakarta. 2007.

Wahidah, N. 2010. Komponen - Komponen yang Memengaruhi Cita Rasa Bahan Pangan. https://www.idazweek.co.cc/2010/02/komponen-komponen-yangmemengaruhi. 
Jurnal Viabel Pertanian Vol. 14 No. 2 November 2020

p-ISSN: 1978-5259 e-ISSN: 2527-3345

Copyright@UNISBA Blitar, http://ejournal.unisbablitar.ac.id/index.php/viabel

Yenny Sri Margianti \& Djalal Su'udi, 2020. Pemanfaatan Limbah Ares Pohon Pisang Menjadi Manisan Ares. Journal Viabel Pertanian. (2020), 14(2) 64-72

Winarno, F.G. 1997. Kimia Pangan dan GIzi. Gramedia Pustaka Utama. Jakarta.

Zuhra, C. F. 2006. Cita Rasa (Flavour). Departemen Kimia FMIPA. Universitas Sumatera Utara. Medan. 